\title{
FACTORS INFLUENCING SUBSTANCE ABUSE AMONG PATIENTS ADMITTED TO THE TWO FEDERAL NEURO-PSYCHIATRIC HOSPITALS IN THE SOUTH- WEST OF NIGERIA
}

\author{
Akindipe Adewole Peter ${ }^{1}$ and Aina Joseph $0 .^{2}$ \\ ${ }^{1}$ Department of Mental Health Nursing, School of Nursing, Babcock University, Ilishan - \\ Remo Ogun State, Nigeria. \\ E - mail: danakindipe@gmail.com \\ ${ }^{2}$ Department of Mental Health Nursing, School of Nursing, Babcock University, Ilishan - \\ Remo Ogun State, Nigeria. \\ E-mail: ainajoe@gmail.com
}

Cite this article:

Akindipe A.P., Aina J.O. (2021), Factors Influencing Substance Abuse among Patients Admitted to the two Federal Neuro-Psychiatric Hospitals in the South-West of Nigeria. African Journal of Health, Nursing and Midwifery 4(2), 38-66. DOI: 10.52589/AJHNMIEQS9BNG.

\section{Manuscript History \\ Received: 1 April 2021 \\ Accepted: 22 April 2021 \\ Published: 27 April 2021}

Copyright $\odot 2020$ The Author(s). This is an Open Access article distributed under the terms of Creative Commons AttributionNonCommercial-NoDerivatives 4.0 International (CC BY-NC-ND 4.0 ), which permits anyone to share, use, reproduce and redistribute in any medium, provided the original author and source are credited.
ABSTRACT: Substance abuse has greatly altered the moral and ethical standard as well as increase insecurity of our society. Hence, this research assessed knowledge and other factors influencing substance abuse among patients admitted to the two Neuropsychiatric Hospitals in South - West, Nigeria. A descriptive cross-sectional design was used. The purposive sampling method was utilized to collect data from 121 respondents from the two hospitals. Self-designed questionnaire was used as an instrument for data collection. Data were analyzed using SPSS version 23. The findings revealed chi - square value obtained for peer pressure is $\left(X^{2}=8.686, P=0.034\right)$, personality trait $\left(X^{2}=11.222\right.$, $P=0.011)$, marital status $\left(X^{2}=31.455, P=0.002\right)$ and occupation $\left(X^{2}=25.266, P=0.046\right)$ at the significant levels less than 0.05 for the four variables respectively. Since these $p$-values were less than 0.05 value, it could be said that peer pressure, personality traits, marital status, and occupation have a significant relationship with substance abuse among patients in neuropsychiatric hospitals. The study concluded that Peer pressure, personality traits occupation, and marital status have influenced patients to substance abuse in the two neuropsychiatric hospitals but knowledge of substance abuse had no influence on substance abuse. Therefore, identifying specific factors that influence clients/patients to substance abuse during the assessment/interaction section may be helpful to give prompt/appropriate intervention that will be more effective.

KEYWORDS: Factors, Patients, peer pressure, personality trait, Substance Abuse 
ISSN: 2689-9418

Volume 4, Issue 2, 2021 (pp. 38-66)

www.abjournals.org

\section{INTRODUCTION}

\section{Background to the Study}

Substance abuse is the consumption of substances that can harm or threaten to harm the physical and mental well-being of an individual. These substances are usually illegal. Substance abuse may be difficult for individuals to manage because of associated psychological issues. According to Ajibade, Uvomata, Akinpelu, Adeleke, Fabiyi, and Akinlabi (2016), substance abuse is cut across all races, cultures, levels of education, and socioeconomic status, leaving no group untouched by its effects.

According to Öztag (2018), substance abuse has become a public health problem that has significant effects on people all over the world threatening the users, their families, the environment, and society. About 275 million people worldwide, which is roughly 5.6 percent of the global population aged 15-64 years, abused drugs at least once during 2016 (United Nations, 2018). Furthermore, United Nations (2018), reported that opioids cause the most harm, accounting for seventy-six percent of deaths where drug use disorders were implicated and more than half of them live with hepatitis $\mathrm{C}$, and one in eight live with Human Immunodeficiency Virus (HIV). In the same vein, social problems and health challenges caused by substance abuse have been very disturbing. Substance abuse has also been associated with social vices such as rape, arm robbery, kidnapping, killing, which is rampaging in the Nigerian communities (Dapap, Okpataku \& Audu, 2020). According to World Health Organization (WHO, 2018), the extent of worldwide psychoactive substance use is estimated at 2 billion for alcohol users, 1.3 billion for smokers, and 185 million for drug users.

Psychoactive substance use cuts across all the geopolitical zones in Nigeria and it appears to be increasing, especially among adolescents. The available report indicates that Nigeria is currently the highest consumer of cannabis and amphetamine in Africa (Ani, 2014). The prevalence of substance abuse in Nigeria was estimated to be 14.4 percent which corresponds to 14.3 million people aged 15-64 years who had used a psychoactive substance for nonmedical purposes. Cannabis is the most commonly used drug and it is seven times higher in men than in women. Nearly one-quarter of high-risk drug users had been arrested for drugrelated offenses during their drug use, while the majority (73 percent) had been arrested for possession of drugs, many high-risk drug users had also been arrested for theft and sex work. Two-thirds of people who used drugs reported having serious problems, as a result of their drug use, such as missing school or work, doing a poor job at work/school, or neglecting their family or children (United Nations Office of Drug and Crime (UNODC), 2018).

Drug addicts manifest unwanted behaviors and more than eighty percent of them indulge in domestic violence (UNODC, 2018). UNODC findings supported the association between drugs and crime. Crimes include drug peddling, petty crimes, and road accidents committed under the influence of alcohol. Furthermore, drug addiction had an impact on work; almost three-fourths of addicts were unable to work, and students could not attend to their studies. Drug addiction was the reason for a change of job in nearly half of workers changing jobs. Adeoti (2015), reiterated the significant association between crimes committed by adolescents and their use of alcohol and other drugs. This shows that many youths can commit crimes under the influence of psychoactive substances. 
ISSN: 2689-9418

Volume 4, Issue 2, 2021 (pp. 38-66)

www.abjournals.org

According to Foo, Tam, and Lee (2015), biology and knowledge play a significant role in substance use. Also, environmental factors which include family factors and peer influence are significant in substance abuse. Psycho-social factors such as poor school achievement and personality traits such as withdrawal/ shyness, aggressive and impulsive behavior, socializing with drug-consuming peers, and genetic predispositions are important in the etiology of addiction. In the study conducted by Zimić, (2018), he enumerated family factors, such as lack of emotional/close relationship between parents and children, particularly with father, a chaotic family environment-especially if parents consume psychoactive substances or if there are mental disorders in the family, ineffective parenting-especially children with severe temperament or with multiple disorders, poor relationship between parents and children and poor parental care.

Studies (Foo, Tam and Lee 2015, Zimić, 2018, Zarrouq 2016), have shown that certain factors such as poor academic performance, impulsivity, peer pressure have a significant influence on the consumption of the psychoactive substance. Therefore, to reduce or prevent social vices, moral decadences and to reduce the crime rate in our society, there is a need to assess factors influencing substance abuse among patients in the two-federal neuro-psychiatric hospitals in the southwest of Nigeria.

\section{Statement of the Problem}

Substance abuse is now recognized as a significant public health problem worldwide (Anyanwu1, Ibekwe \& Ojinnaka 2016). It is estimated that 1 in 20 adults, or a quarter of a billion people between the ages of 15 and 64 years used at least one drug in 2015 (World Drug Report, 2016). In the same vein, United Nations (2018), reiterated that cannabis was by far the most widely consumed drug worldwide in 2016, with 192.2 million past-year users, corresponding to 3.9 percent of the global population aged 15-64 years. High annual prevalence rates of cannabis use continue in West and Central Africa (13.2 percent) (United Nation Office of Drug and Crime 2018).

Furthermore, in Nigeria, one in seven persons aged 15-64 years had used a drug (other than tobacco and alcohol) in the past year corresponding to 14.3 million people of this age group who had used a psychoactive substance in the past year for non-medical purposes (United Nations Office of Drug \& Crime UNODC, 2018). It was reported that the southern geopolitical zone of Nigeria has the highest prevalence of drug use (UNODC 2018). Also, a researcher observed during his clinical experience that the majority of patients treated for substance abuse were readmitted after some months/years. The researcher had once visited a restaurant popularly known as Fela Shrine in Lagos, and the researcher observed that people of high repute in the society also consume cannabis, tobacco, alcohol, and cocaine.

According to a report from Federal Neuropsychiatric Hospital, Yaba Lagos, in 2018 the number of patients diagnosed with substance abuse was 251 while in 2019 (January to May) 167 patients reported abuse substances. In Neuro-Psychiatric Hospital Aro, Abeokuta, the number of patients diagnosed with substance abuse without comorbidity was 97 in 2018 whereas 71 cases of substance abuse were reported from January to May 2019 (Hospital Records). This trend shows evidence that substance abuse is a concern in our society.

The physical, psychological, social, and economic consequences of drug abuse among youth and young adults are becoming more obvious and alarming. Increase crime rate, insecurity, 
domestic violence, rape, poor academic performance and health-related problems such as mental illness have been attributed to substance abuse (Duru, Oluoha, Okafor, Diwe, Iwu, et al. 2017).

Some of the factors contributing to substance abuse have been identified by the previous studies (Palfrey 2015, Duru et al. 2017). Some of these factors were peer pressure, curiosity/ desire for adventure, lack of cordial relationship within the family setting. Despite all efforts to curb substance abuse, it has been observed that this problem is increasing every day. However, the researcher had observed that little has been said about occupation as a factor, influence of social media, personality trait (withdrawal, shyness, impulsiveness), family setting (monogamy, polygamy, divorce, influence of guidance), socio-cultural characteristics, peer pressure. Also, knowledge of substance abuse can be a factor. The majority of the studies were focused on adolescents while little attention has been given to other age groups. This group of people significantly contributed to the stability of a nation. However, if these factors that influence substance abuse are examined, it may generate practicable measures that will help to proffer solutions to the problem. So, the researcher embarked on this study to assess the factor that influences substance abuse among patients in the selected hospitals. I

\section{Objective of the Study}

The main objective of this study is to assess factors influencing substance abuse among patients admitted to the two Neuropsychiatric Hospitals in the South - West of Nigeria.

The specific objectives are to:

1. assess the level of knowledge of substance abuse among the respondents.

2. identify psycho-social factors that influence respondents' substance abuse.

3. identify the common substances of abuse by the respondents.

4. determine socio-cultural characteristics of the respondents as factors influencing substance abuse.

\section{Research Questions}

1. What is the respondent's level of knowledge of substance abuse?

2. What are the psycho-social factors that influence respondent's substance abuse?

3. What are the common substances of abuse by the respondents?

4. What are the socio-cultural characteristics influencing substance abuse?

\section{Hypotheses}

1. $\mathrm{H}_{01}$ : There is no significant relationship between the respondent's psycho-social factors and substance abuse.

2. H02: There is no significant relationship between respondent's knowledge of the substance of abuse and substance abuse.

3. H03: There is no significant relationship between respondent's socio-cultural characteristics and substance abuse. 


\section{Justification of the study}

Substance abuse is public health problem rapidly spreading around the world that threatens the users, their families, environments, and society as a whole. This is causing health problems and devastating societies in psychological and moral terms with an ever more decrease in the age of users. Some factors influence increased engagement in substance abuse in which if these factors are properly identified may provide ways of reducing the consumption of psychoactive substances in our society.

\section{Significance of the Study}

The findings from the study would be used by stakeholders such as health institutions, society groups, professional bodies to plan awareness programs/campaigns that will provide information about the consequences of substance abuse and measures that may be taken to reduce the prevalence of substance abuse to the general public.

Findings from the study would help nurses improve/adjust the existing program package in the treatment of substance abuse by adding vital information to the assessment tool used when conducting one-on-one interaction with the patients. Identification of specific factors will help plan an appropriate individualized intervention that meets patient needs hence promote quick recovery and reduce the length of hospitalization.

The study also would have social significance as the findings may serve as a guide disseminating information to the community to sensitize them about the factors that contribute to substance abuse hence, reducing the prevalence of indiscriminate substance use and thus reducing the negative vices associated with it such as armed robbery, cultism, social violence, rape, etc. This may promote social security and peace within the community. Also, when people who are of productive age are focused and have good conduct in the society, productivity will increase thereby boost the economy of the nation.

The study would help the government to take cognizance of important factors when making policy that will reduce the irrational use of substances in society. This information will promote the effectiveness of such policy and enhance strategies to adopt in the implementation of programs.

\section{Scope of the Study}

This study is limited to respondents admitted at the Drug Abuse Treatment Education and Research (DATER) unit and clinic of the Neuro-Psychiatric Hospital Aro Abeokuta and the Drug ward and clinic of the Neuro-Psychiatric Hospital Yaba Lagos. These are the only federally funded psychiatric hospitals in the southwest of Nigeria.

\section{Operational Definition of Terms}

Substance abuse is the inability to control the use of substances such as cannabis, alcohol, tramadol, pentazocine, cocaine, and diazepam, which can alter mental processes and make patients physically and psychologically dependent on drugs.

Factors are specific variables that influence substance abuse. They include psycho-social, knowledge, and socio-cultural factors. Examples are shown below: 
Psycho-social factors such as peer pressure, social media, occupation, personality trait (such as shyness, withdrawal, impulsiveness), and family setting (monogamy, polygamy, divorce).

Knowledge factor (the knowledge of substance abuse and its consequences).

Socio-cultural factors such as occupation, marital status, religion, level of education, and gender.

Patients: Individuals (15 - 64 years) who are admitted because of substance abuse and are under management or have been treated for substance abuse discharged but still attending drug clinics at Neuropsychiatric hospitals Aro Abeokuta and Yaba Lagos.

\section{LITERATURE REVIEW}

\section{Empirical Review}

Foo, Tam, and Lee (2015) revealed that family factors (such as family economic standing) and peer influence played an important role in an individual's drug abuse habits. Other factors such as curiosity, tension release, and betrayal of the spouse also contributed to the participant's drug abuse. The study also found that a person's drug abuse is usually caused by a combination of several factors instead of just one sole factor. Also, these facts were supported by Alhyas et al., (2015), factors such as peer pressure, inadequate knowledge of the harmful consequences of drug use, family-related (e.g. low monitoring and poor parent-adolescents relationship), affordability, and availability of substances, boredom, and affluence. On the other hand, religiosity was a shield against substance use, especially alcohol.

Anyanwu, Ibekwe, and Ojinnaka, (2016), conducted a study the findings show that Substance abuse was more amongst males, older students, persons from divorced homes, and orphans. It was however less amongst those who frequently participated in religious activities.

In a study conducted by Ikoh, Smah, Kwanya, Clemeny, and Aposhi, (2019), the result identified poor parental relations, availability, and ease of getting drugs in the Metropolis and the neighborhoods as predisposing factors. Each factor tends to reinforce the other. These findings serve to strengthen the arguments of the proponents of social disorganization. Lack of effective parenting have weakened not only the role of guardianship but also training and socializing the child to acceptable norms, rules, and values of the society

Johnson, Akpanekpo, Okonna, Adeboye, and Udoh, (2015), added another factor that the commonest source of substances was from friends while the commonest reasons for substance use were to boost confidence and to read for exams. A statistically significant association existed between substance use and age, sex, intrafamily relationship, family member substance use, peer group use of psychoactive substances, and academic performance. According to this report, alcohol was used by all respondents, while about four out of every ten of them smoked a cigarette, and close to a tenth used marijuana. A similar finding was reported in other studies. In the same report, Several factors tend to predispose to substance use. peer group influence was perceived by more than nine out of every ten respondents as the most common factor predisposing to psychoactive substance use, while up to seven in ten respondents mentioned 
ISSN: 2689-9418

Volume 4, Issue 2, 2021 (pp. 38-66)

www.abjournals.org

stress and more than half thought that curiosity and increased leisure, money also predisposing factors.

Risk factors categorized as familial include childhood maltreatment (abuse \& neglect), familial substance abuse, and parent-child relationships were also contributed to substance abuse. Social risk factors include association with deviant peers, popularity, bullying, and gang affiliation. Individual risk factors include Attention Deficit Hyperactivity Disorder (ADHD) and depression (Whitesell, Bachand, Peel \& Brown 2015).

Related earlier studies propose that adolescents with poor social attachment have weaker selfimage and a greater need to portray themselves to their peers as tough or cool through experimenting with psychoactive substances (Rukundo, Kibanja \& Steffen 2017). Furthermore, (Geramian, Akhavan, Gharaat, Tehrani \& Farajzadegan, 2014), Moore \& Werch cited in (Rukundo, Kibanja \& Steffens 2017), stated that the concern regarding factors responsible for the increasing use of psychoactive substances among adolescents undoubtedly cut across the social care systems including schools.

In a study by Palfrey (2015), it was reported that peer group pressures appeared to influence student's marijuana use, Curiosity and desire for adventure may also contribute to experimentation with drugs. Because these substances give feelings of excitement, such students find it difficult to do without them; they then tend to resort to smoking and drinking to gain a momentary escape from reality (Johnson, Akpanekpo, Okolona \&Udoh 2016) while Haddad, Shotar, and Umlauf (2015), revealed that in-depth knowledge of the consequences of substance abuse was lacking among people.

Akanni, Ehigiator, and Adayonfo (2015) examined the correlates of psychoactive substance use among Nigerian adolescents using a cross-sectional study with secondary school adolescents as participants. The result shows that having a friend who uses substance was significantly associated with tobacco, alcohol, cannabis, and caffeine use while being a male, having a family member that uses substance were significantly associated with tobacco, alcohol, and caffeine use. Older age, lack of satisfaction with the relationship with the teacher, and polygamous family background were significantly associated with tobacco use. And finally, lack of satisfaction with the relationship with parents/guardians and having parents or guardians who are not religious were significantly associated with alcohol use.

Rukundo, Kibanja, and Steffens (2017) conducted a study on the Factors influencing psychoactive substance use in Uganda. The study concluded that Peer influence was pinpointed by all respondents as a major stimulus to adolescent substance use. Participants in this study pointed to their relatives (e.g., parents and siblings) and school neighboring communities as other crucial factors contributing to psychoactive substance use in schools. Whereas several studies pinpoint parental influence as a foremost factor towards substance use, such was not among major arguments for participants of the present study. However, research on neighborhood influences suggests that some ecological factors exert significant influences on adolescent substance use and that social contact among neighbors may be one of the primary mechanisms through which transmission of substance use among students operates Furthermore, exposure opportunities, the present study also reports noteworthy results regarding students' use of psychoactive substances to boost confidence during the entertainment. 
ISSN: 2689-9418

Volume 4, Issue 2, 2021 (pp. 38-66)

www.abjournals.org

Research conducted by Adeoti (2015), the major findings were revealed which include pressure from their friends and gangs"; "initiation by friends". The second major factor is societal such as" I have been enticed by the advertisement". I got the awareness from the advertisement ". The third factor is parental such as "my parents" drinks alcohol". "Deprivation of parental care"; my parents are hostile". The fourth factor is individual such as "I use alcohol to drive away shyness"; "I smoke for excitement and pleasure". The fifth factor is school "the stress in the school"; "frustration from the lecturers".

According to Griffith, France, Bacchus, and Ortega (2018), who examined Childhood Sexual Abuse as a Predictor of Adolescent Substance Abuse. Evidence shows that childhood sexual abuse predicts substance in the adolescence stage of a victim's life. Childhood sexual abuse is associated with various negative outcomes in adolescence such as social withdrawal, depression, and substance use disorders. Childhood maltreatment also leads to instances of anger, aggression, and antisocial behavior. Substance abuse, therefore, acts as a way of easing the pain and suffering caused by the traumatic sexual abuse event thus reducing the negative effects associated. Concisely, childhood sexual abuse facilitates the development of revictimization and vulnerability in later life, which amplifies the victim's risk of adolescent drug use. When treating substance abuse disorders during adolescence.

Alhyas, Elarabi, El-Kashef, Wanigaratne, et al. (2015), investigated Adolescents' perception of substance use The impact of peer pressure on teenagers' behavior is well documented in the literature and is considered as one of the most influential factors in substance abuse. Other studies found that the power of peers in enforcing the behavior of substance abuse was greater than the family's protective role. Boredom, unutilized free time, and lack of community-based activities were other substance use risk factors reported by a number of the study participants residing in the Western region. The availability and affordability of substances, specifically tobacco product, were believed to be strong risk factors for substance use among adolescents

Many studies that have investigated the correlation of demographic and socioeconomic variables with the abuse of psychoactive substances have shown that a high degree of religiosity, higher parent's education living with one or both parents reduce the chance to abuse, while high the

socio-economic status of the family increases the likelihood of psychoactive substances use Goodman and Huang; Hanson and Chen; Schoenberg and Adams, Cited in (Katarina 2017). Children who come from wealthier families with higher socioeconomic status may be at increased risk for the abuse of psychoactive substances which can be explained by the fact that they experience more pressure achievement combined with isolation of parents who have careers more demanding. Also, parents with higher socioeconomic status in comparison with those in the lower socioeconomic status families can have positions that are tolerant of substance abuse. The higher-income families may be related to the use of psychoactive substances because of increased access to, or to buy the substance and have a social association with others who also have financial resources. On the other hand, a lower revenue may be associated with the abuse of psychoactive substances such as the mechanism of survival due to increased stress and less access to alternative actions that can be a focal point for preventive strategies (Katarina, 2017). 
ISSN: 2689-9418

Volume 4, Issue 2, 2021 (pp. 38-66)

www.abjournals.org

Adewumi (2017), conducted a study on the psychosocial factors influencing substance abuse. it was revealed that most of the abusers have good knowledge of substance abuse and its consequences. They also have a strong desire to quit it but their addictive nature has been a factor making their effort abortive.

According to Duru, Oluoha., Okafor., Diwe, Iwu., Aguocha et al., (2017), who investigated the socio-demographic determinants of psychoactive substance use, findings revealed that male students consumed psychoactive substance than female. Medical students were less likely to use psychoactive substances when compared to others. Also, poor parenting or individuals from broken homes have a greater chance of abusing substances than others. The study revealed that students with a low level of education abuse substances than students with a higher level of education.

In a study carried out by Diraditsile and Rasesigo (2018), the participants expressed that the possible effects of substance abuse on mental health are depression, stress disorders, personality disorders, mood disorders, psychotic disorders, and suicidal tendencies; of which most markedly pointed out depression to be the most likely and most common. Some reported an already existing diagnosis of depression due to substance abuse. It was also observed that mood disorders were present occurring concurrently with depression, and leading to feelings of irritability and hopelessness.

Njoroge (2017) conducted a study on Knowledge, Attitude, and Practices on Substance Use Disorders by University Students: the finding reviewed that student lack of knowledge of the risk of substance use increases their consumption of the psychoactive substance. He identifies the predisposing factors as substance availability and internet, technology, and media influence.

The 2016 National Survey on Drug Use and Health showed that in 2016, 28.6 million people aged 12 or older used an illicit drug during the past 30 days, which corresponds to about 1 in 10 Americans overall (10.6\%). For adults ages 18-25, that range was about 1 in 4 . Despite the age variance, illicit drug use estimated for that year was driven primarily by marijuana use and the misuse of prescription pain relievers. Survey results indicated that among 24.0 million were marijuana users and 3.3. Million misused prescriptions pain relievers (Finch 2018).

\section{THEORETICAL FRAMEWORK}

\section{Theory of Reasoned Action}

This theory suggests that a person's behavior is determined by the individual deliberate thinking to perform the behavior and that this determination is, in turn, a function of the attitude towards the behavior and subjective norms. Attitudes (individual judgment about certain actions either positive or negative), and subjective norms were the perceived social pressure to perform or not perform the target behavior. In general, a strong attitude and subjective norms lead to a stronger intention to perform the behavior. (Fishbein \& Ajzen, 1975).

Attitude is an individual's positive or negative feelings about a particular behavior. An individual $\mathrm{s}$ belief about the consequences of a particular behavior forms his/her attitude 
ISSN: 2689-9418

Volume 4, Issue 2, 2021 (pp. 38-66)

(behavioral belief) weighted by his/her assessment of these consequences (outcome evaluation). This attitude is the positive or negative belief or outcome of one's behavior.

Subjective Norm is an individual's perception about those you hold in high esteem should or should not perform the behavior in question. Subjective norm is significantly influenced by two important factors: Conceived expectations from other people and the actual driving force to go for this expectation and behave in such a manner.

Normative social influence: This defines how other people influence individuals to act to be accepted and liked by others. Even though you don't approve of a particular behavior, normative social influences exert so much pressure on an individual to comply with the group's social norms. Normative social influence has been proven to exert a high persuasive force on individuals. A person tends to behave the way he/she feels significant others expect $\mathrm{him} /$ her to behave. These significant others might be close associates like friends, spouses, or close relatives amidst others. One can assess these by asking respondents to judge what those people who are important to them would do in some situations.

Tenets of the theory of reasoned action

- Behavioral outcome and public opinion determine an individual's behavior.

- Behavior is affected by intention to shape the behavior and this intention is a product of subjective norm and attitude of behavior.

- Attitude is the result of an individual feeling about what the outcome of behavior should look like.

Perceived behavioral Control; This explains howbeit behavior is the product of one's intention to do something and for this to happen, this behavior has to be under volitional control which helps one to decide at will whether to engage in it or not.

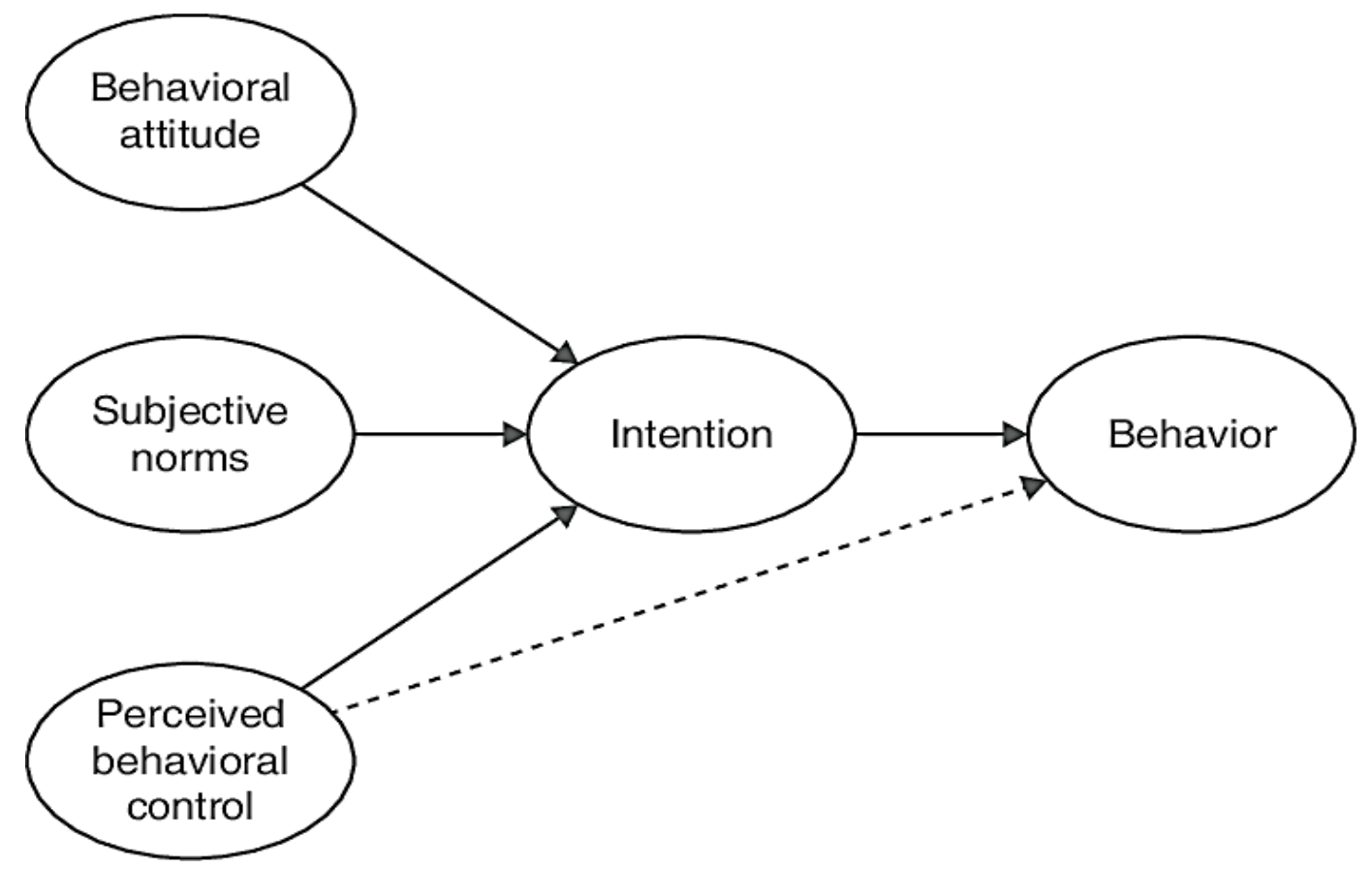

Figure 1: Theory of reasoned action by Fishbein and Ajzen, (1975). 


\section{Application of the theory of reasoned action to this Study}

The central construct of the theory is an intention, a motivational construct that is considered the most proximal determinant of behavior. Intention reflects the extent to which an individual is likely to plan to do and invest effort in pursuing a given behavior. The intention is conceptualized as a function of two belief-based constructs: attitudes and subjective norms. These two beliefs - based constructs are subjected to some background factors namely:

Disposition: this is the genetic make-up of the individual that affects self-efficacy. It includes personality traits such as self-esteem and emotions. These factors determine an individual ability accept or reject a behavior been influenced by significant others such as friends/peers, family members.

Demographic factors influence an individual's ability to take a concrete decision about certain behavior. Demographic factors are age, level of education, occupation, family structure, and religion.

Information: the level of exposure or knowledge of consequences and perceived benefits of a substance may determine individual attitude towards substance abuse.

Attitude toward the behavior: these are the perceived benefit for the individual which may stimulate behavior towards substance abuse. The perceived benefit such as social acceptance by peers, boldness, forgetting one's problem.

Subjective Norms: These are significant orders that may influence intention whether to accept certain behaviors or not. These are the factors such as peer pressure, experience, and social medial. At this level, if a modality can be developed that reinforces positive behavior such as youth social club on substance abuse and policy that control the use of substances. This will create an avenue for changing people's orientation about substance abuse. Also, it may reinforce an individual positive attitude and inhibit negative intentions that may result in moral behavior towards substance use.

Behavioral Intention: This is the decision individual resolves to take after evaluation of the advance of the significant order and explicit analysis of the factors considered by the individual. This behavioral intention precedes and influences outcome behavior which is substance abuse. 
African Journal of Health, Nursing and Midwifery

ISSN: 2689-9418

Volume 4, Issue 2, 2021 (pp. 38-66)

www.abjournals.org

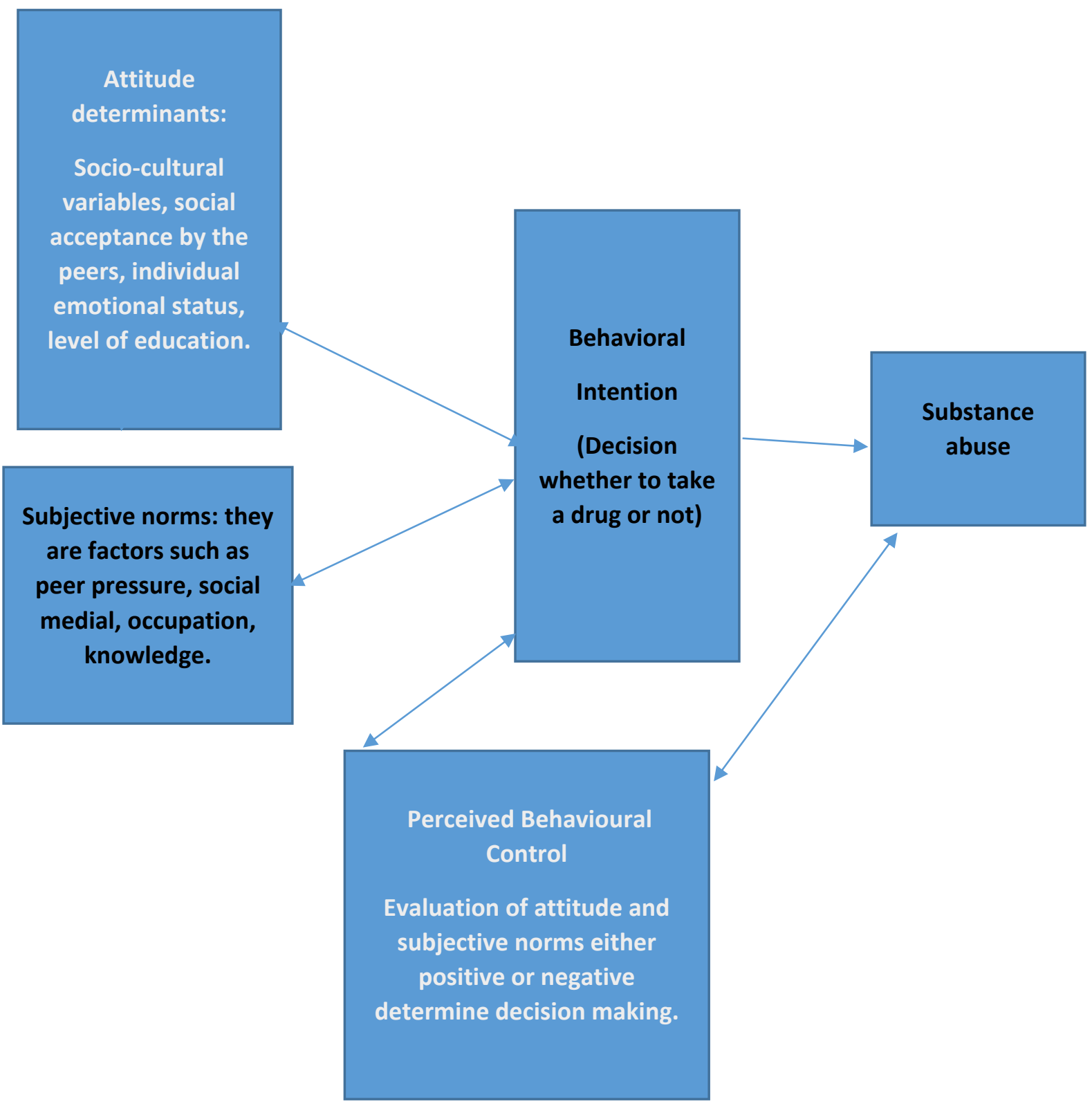

Figure 2: Conceptual framework for the study adapted from theory of reasoned action by Fishbein and Ajzen, (1975). 
ISSN: 2689-9418

Volume 4, Issue 2, 2021 (pp. 38-66)

\section{METHODOLOGY}

\section{Research Design}

This study is descriptive and utilized a cross-sectional survey design to assess factors that influence substance abuse among patients admitted to the two selected neuropsychiatric hospitals in southwest Nigeria. The study is cross-sectional because research is expected to be conducted within a limited time.

\section{Research Setting}

The study was conducted in the two Federal Neuropsychiatric Hospitals situated in South West of Nigeria; namely Federal Neuropsychiatric Hospital, Aro, Abeokuta Ogun State, and Federal Neuro-Psychiatric hospital Yaba, Lagos.

\section{Population}

The target population for this study was the patients admitted to the drug treatment unit or attending the drug clinic of the Federal Neuropsychiatric hospitals Aro, Abeokuta, Ogun State, and Neuro-Psychiatric Hospital Yaba, Lagos. The patients who were diagnosed and admitted because of substance abuse or who have been discharged but still attending drug clinics of the hospitals constituted the population for this study. The total population for the study was 160 respondents.

\section{Table 3. 1: Estimation of the target population}

\begin{tabular}{|c|c|c|c|}
\hline \multirow{2}{*}{$\begin{array}{l}\text { Federal } \\
\text { Neuropsychiatric } \\
\text { Hospital Aro, } \\
\text { Abeokuta }\end{array}$} & Drug wards & 42 respondents & \multirow[t]{2}{*}{ Total: 72} \\
\hline & $\begin{array}{l}\text { Drug clinic runs once } \\
\text { a month: average per } \\
\text { clinic was } 15\end{array}$ & For two months: 30 & \\
\hline & Drug wards & 40 respondents & \multirow[t]{2}{*}{ Total: 88} \\
\hline $\begin{array}{l}\text { Neuropsychiatric } \\
\text { Hospital Yaba, } \\
\text { Lagos. }\end{array}$ & $\begin{array}{l}\text { Drug clinic runs } \\
\text { weekly: average per } \\
\text { clinic was } 8\end{array}$ & $\begin{array}{l}\text { For } 6 \text { weeks }=48 \\
\text { respondents }\end{array}$ & \\
\hline Total & & & 160 Respondents \\
\hline
\end{tabular}

Inclusion Criteria: Those admitted to DATER phase II of the neuropsychiatric hospital, Aro, Abeokuta, or those who have been discharged and attending drug clinics of the hospitals. Also, respondents between ages $15-64$ years were included. Respondents who were identified by the nurses as fit to participate in the study. Respondents who were willing to participate in the study.

Exclusion Criteria: Respondents who were still receiving treatment for comorbidity. Those below age 15 years and respondents above age 64 years. 


\section{Sample size determination and sampling technique}

A purposive sampling technique was used. Purposive because only respondents who have commenced treatment for substance abuse only and those who were selected by the nurses as fit for the study were used. A total of 127 respondents were involved in the study. A total number of 59 respondents were involved from Federal Neuro-Psychiatric Hospital Aro, Abeokuta while 68 respondents were involved from Federal Neuro-Psychiatric Hospital Yaba, Lagos.

\section{Instrumentation}

The instrument used in the collection of data was a self-designed questionnaire constructed by the researcher to get detailed information from the respondents in the two hospitals. The questionnaire contains four main sections as described below.

SECTION A: Socio-demographic characteristics: this includes age, occupation, level of education, marital status, religion, parent's level of education.

SECTION B contains knowledge of substance abuse which was designed to produce true or false answers. The items were eight in number; the response column contains true/false. The maximum point is eight.

\section{Scoring}

Scores between 6 and 8 were categorized as good knowledge

Scores between 3 and 5 were categorized as fair knowledge

Scores 2 and below categorized as poor knowledge

SECTION C: Psycho-social factors influencing substance abuse. The following factors were considered: Occupation, peer pressure, personality traits, social media, and family setting. The instrument required YES or NO answers.

SECTION D: specific substances of abuse: this contains drugs of abuse and was designed to respond on 4 points Likert scale such as 'once in a while' rated 1, during weekends rated 2, three times in a week rated 3, and daily/very often rated 4.

\section{Validity and Reliability of the Instrument}

Validity: To ensure the face and content validity, the questionnaire was designed based on the objectives of the study, was supervised and approved by the research supervisor and other experts in the field.

Reliability: To ascertain the internal consistency and stability of the instrument, a pilot test was conducted at Lagos University Teaching Hospital, Lagos using respondents with similar characteristics. 16 questionnaires (i.e $10 \%$ of the proposed sample size) were administered to the respondents who abuse substances and have gained mental stability based on the experts' judgment. The Cronbach alpha for each section was determined as .727, .782, and .730 for sections $\mathrm{B}, \mathrm{C}$, and $\mathrm{D}$ respectively. 


\section{Procedure for Data Collection}

The researcher collected a letter of introduction from the Dean, School of Nursing, Babcock University. The letter was presented to the chairman, ethical committees of the two hospitals for the study. The researcher used a self-designed questionnaire with the help of a research assistant to collect data. Before collecting data from respondents, the content of the questionnaire was explained to the respondents in the language they understood and the same retrieved immediately. A total number of 59 respondents were involved from Federal NeuroPsychiatric Hospital Aro Abeokuta while 68 respondents were involved from Federal NeuroPsychiatric Hospital Yaba Lagos. The data were collected within 2 months from the two hospitals using the purposive sampling method.

\section{Method of Data Analysis}

Data gathered from the study were analyzed using quantitative methods. Descriptive statistical tools like frequency tables, percentages, and cross-tabulation were employed to report the research findings while the inferential statistical tool (Chi-square) was used to test the research hypotheses. The hypotheses formulated for the study were tested at a 0.05 level of significance. All procedures for data analysis were carried out using SPSS software (version 23).

\section{Ethical Considerations}

Ethical approval for the study was obtained from Babcock University Health Research Ethical Committee (BUHREC). Respondents were asked for their willingness to participate in the study and those that give consent were allowed to participate.

The informed consent form was given to the respondents and an explanation on any aspect was given if respondents request such explanations. Also, the principle of autonomy and confidentiality was maintained. The researcher ensured consideration of patient language. Information was provided in the language patient understand. The benefit of this study is to use information gotten from the study is used to plan strategies that may be useful in curbing consumption of psychoactive substances.

\section{DATA ANALYSIS, RESULTS AND DISCUSSION OF FINDINGS}

Chi-square was used to test the three hypotheses. The result from each of the institutions was done separately for descriptive analysis. The total number of respondents who participated in the study was 127, however, 6 questionnaires were not properly filed and counted as invalid. Therefore, 121 questionnaires were used for analysis; 55 respondents from the Neuropsychiatric hospital Aro, Abeokuta and 66 respondents from the Neuropsychiatric hospital Yaba. 
African Journal of Health, Nursing and Midwifery

ISSN: 2689-9418

Volume 4, Issue 2, 2021 (pp. 38-66)

\section{Presentation of Result}

Table 4.1: Respondent's Socio-Demographic characteristics ( $n=121)$

\begin{tabular}{|c|c|c|c|c|c|c|}
\hline & & \multicolumn{2}{|c|}{ YABA } & \multicolumn{2}{|c|}{ ARO } & \multirow[b]{2}{*}{ Total } \\
\hline Variables & & $\begin{array}{c}\text { Frequenc } \\
y\end{array}$ & Percent & $\begin{array}{c}\text { Frequenc } \\
\mathrm{y}\end{array}$ & Percent & \\
\hline \multirow[t]{6}{*}{ Age } & $10-20$ & 4 & 6.1 & 6 & 10.9 & $10(8.3 \%)$ \\
\hline & $21-30$ & 42 & 63.6 & 32 & 58.2 & $74(61.15)$ \\
\hline & $31-40$ & 14 & 21.2 & 13 & 23.6 & $27(22.3 \%)$ \\
\hline & $41-50$ & 3 & 4.5 & 2 & 3.6 & $5(4.2 \%)$ \\
\hline & Above 50 & 3 & 4.5 & 2 & 3.6 & $5(4.2 \%)$ \\
\hline & Total & 66 & 100.0 & 55 & 100.0 & \\
\hline \multirow[t]{3}{*}{ Gender } & Male & 62 & 93.9 & 50 & 90.9 & $\begin{array}{r}112(92.5 \\
\%)\end{array}$ \\
\hline & Female & 4 & 6.1 & 5 & 9.1 & $9(7.4 \%)$ \\
\hline & Total & 66 & 100.0 & 55 & 100.0 & \\
\hline \multicolumn{7}{|l|}{ Religion } \\
\hline & Christianity & 42 & 63.6 & 42 & 76.4 & $84(69.4 \%)$ \\
\hline & Islam & 20 & 30.3 & 11 & 20.0 & $32(26.5 \%)$ \\
\hline & Traditional & 4 & 6.1 & 1 & 1.8 & $5(4.2 \%)$ \\
\hline & Others & 0 & 0 & 1 & 1.8 & \\
\hline & Total & 66 & 100.0 & 55 & 100.0 & \\
\hline \multicolumn{7}{|l|}{$\begin{array}{l}\text { Marital } \\
\text { status }\end{array}$} \\
\hline & Single & 55 & 83.3 & 43 & 78.2 & $98(81 \%)$ \\
\hline & Married & 9 & 13.6 & 3 & 5.5 & $12(9.9 \%)$ \\
\hline & Separated & 2 & 3.0 & 4 & 7.3 & $6(4.9 \%)$ \\
\hline & Divorced & 0 & 0 & 1 & 1.8 & $1(0.8 \%)$ \\
\hline & no response & 0 & 0 & 4 & 7.3 & \\
\hline & Total & 66 & 100.0 & 55 & 100.0 & \\
\hline \multirow[t]{7}{*}{ Occupation } & Student & 26 & 39.4 & 21 & 38.2 & $47(38.8 \%)$ \\
\hline & $\begin{array}{l}\text { Civil } \\
\text { servant }\end{array}$ & 1 & 1.5 & 4 & 7.3 & $5(4.1 \%)$ \\
\hline & $\begin{array}{l}\text { Working } \\
\text { with a } \\
\text { private firm }\end{array}$ & 13 & 19.7 & 7 & 12.7 & $20(16.5 \%)$ \\
\hline & $\begin{array}{l}\text { Self- } \\
\text { employed }\end{array}$ & 22 & 33.3 & 19 & 34.5 & $41(33.9 \%)$ \\
\hline & Others & 4 & 6.1 & 1 & 1.8 & $5(4.1 \%)$ \\
\hline & no response & 0 & 0 & 3 & 5.5 & \\
\hline & Total & 66 & 100.0 & 55 & 100.0 & \\
\hline
\end{tabular}


African Journal of Health, Nursing and Midwifery

ISSN: 2689-9418

Volume 4, Issue 2, 2021 (pp. 38-66)

www.abjournals.org

\begin{tabular}{|l|l|r|r|r|r|r|}
\hline $\begin{array}{l}\text { Level of } \\
\text { education }\end{array}$ & Primary & 1 & 1.5 & 4 & 7.3 & $5(4.1 \%)$ \\
\hline & Secondary & 20 & 30.3 & 16 & 29.1 & $36(29.8 \%)$ \\
\hline & Tertiary & 44 & 66.7 & 35 & 63.6 & $79(65.3 \%)$ \\
\hline & no response & 1 & 1.5 & 0 & 0 & - \\
\hline & Total & 66 & 100.0 & 55 & 100.0 & \\
\hline
\end{tabular}

As shown in Table 4.1 above, the majority of the respondents were young adults in both institutions with a mean age of 27.4 . The table revealed that $92.5 \%$ were male while $7.5 \%$. Respondents' marital status shows that the majority $(81 \%)$ were single while only $12 \%$ were married.

\section{Factors Influencing Substance Abuse}

Table 4. 2: Respondent's Knowledge level on Substance abuse

\begin{tabular}{|c|c|c|c|c|c|c|}
\hline \multicolumn{7}{|c|}{ Level of knowledge } \\
\hline & \multicolumn{2}{|c|}{ YABA } & \multicolumn{2}{|c|}{$\mathrm{ARO}$} & \multicolumn{2}{|c|}{ Both Institutions } \\
\hline Level/Scoring & Frequency & Percent & Frequency & Percent & Frequency & Percent \\
\hline $\begin{array}{l}\text { Good knowledge } \\
(6-8)\end{array}$ & 40 & 60.6 & 32 & 58.2 & 72 & 59.5 \\
\hline $\begin{array}{l}\text { Fair knowledge } \\
(3-5)\end{array}$ & 25 & 37.9 & 22 & 40.0 & 47 & 38.9 \\
\hline $\begin{array}{l}\text { Poor knowledge } \\
(0-2)\end{array}$ & 1 & 1.5 & 1 & 1.8 & 2 & 1.6 \\
\hline Total & 66 & 100.0 & 55 & 100.0 & 121 & 100 \\
\hline
\end{tabular}

Table 4.2 shows respondents' knowledge level on substance abuse. The majority of the respondents $(60.6 \%)$ have good knowledge in Yaba likewise 58.2\% in Aro. This table indicates that the majority of respondents who abuse substances have good knowledge of substance abuse and its consequences. This may the result of the intervention of the health workers as respondents have commenced treatment for substance abuse.

Table 4.3: psychosocial factors influencing respondents' substance abuse

\begin{tabular}{|l|l|l|l|}
\hline Factors & Yaba & Aro & Total \\
\hline Peer pressure & $45(68.2 \%)$ & $39(70.9 \%)$ & $84(69.4 \%)$ \\
\hline social media & $26(39.4 \%)$ & $24(43.6 \%)$ & $50(41.3 \%)$ \\
\hline occupation & $18(27.3 \%)$ & $24(43.6 \%)$ & $42(34.7 \%)$ \\
\hline Family settings & $24(36.4 \%)$ & $21(38.2 \%)$ & $45(37.2 \%)$ \\
\hline Personality trait & $49(74.2 \%)$ & $37(67.3 \%)$ & $86(71.1 \%)$ \\
\hline
\end{tabular}

Table 4.3 shows factors that influence substance abuse which was identified as peer pressure, social media, occupation, family settings, personality traits. The table revealed that the majority $69.4 \%$ and $71.1 \%$ were influenced into substance through peer pressure and 
African Journal of Health, Nursing and Midwifery

ISSN: 2689-9418

Volume 4, Issue 2, 2021 (pp. 38-66)

www.abjournals.org

personality trait. The table also revealed that seven out of ten respondents were enticed to substance use either by peer pressure or a personality trait.I

Table 4.4: Respondents' choice of Substances of abuse

\begin{tabular}{|l|l|l|l|l|}
\hline Substance & Yaba & Aro & Total & Rank \\
\hline Alcohol & $35(53 \%)$ & $45(81.8 \%)$ & $80(66.1 \%)$ & $2^{\text {nd }}$ \\
\hline Cannabis & $47(71.2 \%)$ & $38(69.1 \%)$ & $85(70.2 \%)$ & 1 st \\
\hline Tramadol & $11(16.7 \%)$ & $12(21.8 \%)$ & $21(19 \%)$ & $5^{\text {th }}$ \\
\hline Pentazocine & $3(4.6 \%)$ & $7(12.7 \%)$ & $10(8.3 \%)$ & $7^{\text {th }}$ \\
\hline Codeine & $24(36.4 \%)$ & $17(25.5 \%)$ & $41(33.8 \%)$ & $3^{\text {rd }}$ \\
\hline Diazepam & $6(9.1 \%)$ & $5(9.1 \%)$ & $11(9.1 \%)$ & $6^{\text {th }}$ \\
\hline Cocaine & $14(21.2 \%)$ & $11(20 \%)$ & $25(20.7 \%)$ & $4^{\text {th }}$ \\
\hline
\end{tabular}

Table 4.4 indicates the prevalence of substance of abuse. It was observed that respondents in Aro $(81.8 \%)$ abuse alcohol than respondents in Yaba (53\%). Also, respondents abuse cannabis in Yaba (71.2\%) than Aro (69.1\%). This table indicates that cannabis has the highest prevalence, followed by alcohol then codeine while pentazocine $(8.3 \%)$ and diazepam $(9.1 \%)$ have the lowest prevalence.

Table 4.5: Frequency of use of the substance of abuse

\begin{tabular}{|l|l|l|l|}
\hline Frequency of use & Yaba & Aro & Total \\
\hline Once a week & $5(7.6 \%)$ & $2(5.5 \%)$ & $7(5.8 \%)$ \\
\hline Weekends & $5(7.6 \%)$ & $9(16.4 \%)$ & $14(11.6 \%)$ \\
\hline Three times a week & $6(9.1 \%)$ & $11(20 \%)$ & $17(14.1 \%)$ \\
\hline Daily & $50(75.8 \%)$ & $33(60 \%)$ & $83(68.6 \%)$ \\
\hline Total & 66 & 55 & $121(100 \%)$ \\
\hline
\end{tabular}

Table 4.5 indicates the frequency of substance of abuse. A majority (68.6\%) takes substance every day, $14.1 \%$ of the respondents take drugs three times a week while $11.6 \%$ and $5.8 \%$ consumed substance on weekends and once a week respectively.

\section{Research hypotheses}

Hypothesis one: There is no significant relationship between psychosocial factors and substance abuse 
African Journal of Health, Nursing and Midwifery

ISSN: 2689-9418

Volume 4, Issue 2, 2021 (pp. 38-66)

www.abjournals.org

Table 4.6 shows the relationship between psycho-social factors and substance abuse.

\begin{tabular}{|c|c|c|c|c|c|c|c|}
\hline \multirow[t]{2}{*}{ variables } & \multicolumn{4}{|c|}{ Frequency of Substance abuse } & \multirow[t]{2}{*}{ Total } & \multirow[t]{2}{*}{$\mathrm{X}^{2}$} & \multirow{2}{*}{$\begin{array}{l}\mathrm{P}- \\
\text { value }\end{array}$} \\
\hline & $\begin{array}{l}\text { Once a } \\
\text { week }\end{array}$ & $\begin{array}{l}\text { Weekend } \\
\text { only }\end{array}$ & $\begin{array}{l}\text { Three } \\
\text { times a } \\
\text { week }\end{array}$ & $\begin{array}{l}\text { Daily } \\
\text { substance } \\
\text { intake }\end{array}$ & & & \\
\hline \multicolumn{6}{|c|}{ Peer pressure } & \multirow[b]{3}{*}{8.696} & \multirow[b]{3}{*}{$.034 * *$} \\
\hline Yes & 5 & 7 & 13 & 74 & 99 & & \\
\hline No & 2 & 3 & 2 & 15 & 22 & & \\
\hline \multicolumn{6}{|c|}{ Social media } & \multirow{3}{*}{1.550} & \multirow{3}{*}{.671} \\
\hline Yes & 2 & 3 & 6 & 47 & 58 & & \\
\hline No & 4 & 6 & 7 & 46 & 63 & & \\
\hline \multicolumn{6}{|c|}{ Personality trait } & \multirow{3}{*}{11.222} & \multirow{3}{*}{$.011 * *$} \\
\hline Yes & 2 & 4 & 11 & 78 & 96 & & \\
\hline No & 3 & 5 & 2 & 15 & 25 & & \\
\hline \multicolumn{6}{|c|}{ Family settings } & \multirow{3}{*}{3.002} & \multirow{3}{*}{.391} \\
\hline Yes & 2 & 4 & 3 & 44 & 53 & & \\
\hline No & 4 & 5 & 10 & 49 & 68 & & \\
\hline
\end{tabular}

Table 4.6 shows that the chi-square value obtained for peer pressure is $\left(\mathrm{X}^{2}=8.686, \mathrm{P}=0.34\right)$ and personality trait $\left(\mathrm{X}^{2}=11.222, \mathrm{P}=0.11\right)$ at the significant levels less than 0.05 for the two variables respectively. Since these $\mathrm{p}$ - values were less than 0.05 values, it could be said that peer pressure and personality trait have a relationship with substance abuse among patients in neuropsychiatric hospitals.

However, for social media and family settings, the chi-square values obtained were 1.550 and 3.002 respectively at an insignificant level of 0.671 for social media and 0.391 for family settings. It could be said that social media and family settings have no relationship with substance abuse among patients in neuropsychiatric hospitals.

\section{Hypothesis two}

$\mathrm{H}_{1}$ : There is no significant relationship between respondent's knowledge of substance abuse and abuse of the substance

Table 4.7: shows the relationship between knowledge level and abuse of a substance

\begin{tabular}{|c|l|l|l|l|l|l|l|}
\hline \multirow{2}{*}{$\begin{array}{c}\text { Knowledge of } \\
\text { substance abuse }\end{array}$} & \multicolumn{3}{|c|}{ Frequency of substance abuse } & Total & & \\
\cline { 2 - 8 } & $\begin{array}{l}\text { Once a } \\
\text { week }\end{array}$ & $\begin{array}{l}\text { Weekend } \\
\text { only }\end{array}$ & $\begin{array}{l}\text { Three } \\
\text { times a } \\
\text { week }\end{array}$ & $\begin{array}{l}\text { Daily } \\
\text { substance } \\
\text { intake }\end{array}$ & & & \\
\hline $\begin{array}{l}\text { Good knowledge } \\
\text { fair knowledge }\end{array}$ & 3 & 3 & 8 & 60 & 74 & 3.690 & 0.297 \\
value & \\
Total & 6 & 6 & 5 & 33 & 47 & & \\
\hline
\end{tabular}


African Journal of Health, Nursing and Midwifery

ISSN: 2689-9418

Volume 4, Issue 2, 2021 (pp. 38-66)

www.abjournals.org

Table 4.7 shows that the chi-square obtained for knowledge is $\left(X^{2}=3.690, P=0.297\right)$. Since the $\mathrm{p}$-value is greater than 0.05 level of significance, it could be deduced that knowledge has no significant relationship with substance abuse among patients admitted to neuropsychiatric hospitals.

\section{Hypothesis Three:}

$\mathrm{H}_{1}$ : There is no significant relationship between respondent's socio-cultural characteristics and substance abuse

Table 4.8 shows the relationship between socio-cultural characteristics and substance abuse

\begin{tabular}{|c|c|c|c|c|c|c|c|}
\hline \multirow[t]{2}{*}{ variables } & \multicolumn{4}{|c|}{ Frequency of Substance abuse } & \multirow{2}{*}{$\begin{array}{l}\text { Tot } \\
\text { al }\end{array}$} & \multirow[t]{2}{*}{$\mathrm{X}^{2}$} & \multirow[t]{2}{*}{ P-value } \\
\hline & $\begin{array}{l}\text { Once a } \\
\text { week }\end{array}$ & $\begin{array}{l}\text { Weekend } \\
\text { only }\end{array}$ & $\begin{array}{l}\text { Three } \\
\text { times a } \\
\text { week }\end{array}$ & $\begin{array}{l}\text { Daily } \\
\text { substance } \\
\text { intake }\end{array}$ & & & \\
\hline \multicolumn{8}{|l|}{ Gender } \\
\hline Male & 5 & 8 & 12 & 87 & 112 & \multirow[t]{2}{*}{1.051} & \multirow[t]{2}{*}{0.789} \\
\hline Female & 1 & 1 & 1 & 6 & 9 & & \\
\hline \multicolumn{8}{|l|}{ Religion } \\
\hline Christianity & 5 & 4 & 10 & 65 & 84 & \multirow[t]{2}{*}{6.399} & \multirow{2}{*}{.699} \\
\hline Islam & 1 & 6 & 3 & 27 & 37 & & \\
\hline \multicolumn{8}{|l|}{ Marital status } \\
\hline Single & 6 & 5 & 10 & 79 & 100 & \multirow[t]{2}{*}{31.455} & \multirow[t]{2}{*}{$.002 * *$} \\
\hline Married & 4 & 2 & 5 & 10 & 21 & & \\
\hline \multicolumn{8}{|l|}{ Occupation } \\
\hline Students & 1 & 3 & 4 & 40 & 48 & \multirow[t]{2}{*}{25.266} & \multirow[t]{2}{*}{$.046 * *$} \\
\hline Working-class & 5 & 5 & 10 & 53 & 72 & & \\
\hline \multicolumn{8}{|l|}{$\begin{array}{l}\text { Level of } \\
\text { education }\end{array}$} \\
\hline Basic education & 2 & 4 & 5 & 29 & 40 & \multirow[t]{2}{*}{5.174} & \multirow[t]{2}{*}{.819} \\
\hline Tertiary & 6 & 6 & 10 & 59 & 81 & & \\
\hline
\end{tabular}

** = significant at less than 0.05

Table 4.8 shows that the chi-square value obtained for marital status is $\left(\mathrm{X}^{2}=31.455, \mathrm{P}=\right.$ $0.002)$ and occupation $\left(X^{2}=25.266, P=0.046\right)$ at the significant levels less than 0.05 for the two variables respectively. Since these $\mathrm{p}$ - values were less than 0.05 values, it could be said that marital status and occupation have a relationship with substance abuse among patients in neuropsychiatric hospitals.

However, for gender, religion, and family settings, the chi-square values obtained were $1.051,6.399$, and 5.174 respectively at an insignificant level of 0.789 for gender, 0.699 for religion, and 0.819 for the level of education. It could be said that gender, religion, and level 
ISSN: 2689-9418

Volume 4, Issue 2, 2021 (pp. 38-66)

www.abjournals.org

of education have no relationship with substance abuse among patients in neuropsychiatric hospitals.

\section{DISCUSSION OF FINDINGS}

Research question 1: What is the respondent's level of knowledge of substance abuse?

Table 4.2 Shown the level of knowledge of respondents on substance abuse in both institutions. $72(59.5 \%)$ have good knowledge of substance abuse while $47(38.9 \%)$ have a fair knowledge of substance abuse. This finding was consistent with the research of Adewumi (2017), which state that most of the abuser has good knowledge of substance abuse and its consequences. They also have a strong desire to quit it but their addictive nature has been a factor making their effort abortive.

However, people who scored high on knowledge of substance abuse still believed that anybody engaged in abusing substance can stop it whenever he/she wishes and function optimally in society. Despite that they have good knowledge, the denial state persists and may have a major effect on their behavior. Also, the good knowledge of substance abuse that the majority of the respondents in neuropsychiatric hospitals displaced may be the effect of treatment they received from nurses and doctors since these respondents have commenced treatment for substance abuse. Therefore, psycho-education on the consequences of substance abuse at the early stage of life can be helpful to reduce the prevalence of substance abuse in our society.

Research question 2: What are the psycho--social factors that influence respondent's substance abuse?

Four specific factors were identified which include; peer influence, social media, family setting, and personality traits. Table 4.3 revealed factors that influence respondents' substance abuse. The majority $84(69.4 \%)$ were introduced into substance through a friend/neighbor. This finding is of the research of Foo, Tam, \& Lee (2015); similarly, Johnson, Akpanekpo, Okonna, Adeboye, \& Udoh, (2015). Also, Palfrey (2015), Duru, Oluoha, Okafor, Diwe, Iwu, Aguocha, Ohale \& Nwaigbo (2017), is consistent with this research which state that peer pressure is one of the major factors that influence an individual to drug use. The table also revealed the influence of social media on substance abuse. 50(41.3\%) said information about psychoactive drugs was gotten from social media. The finding was agreed with Adeoti (2015) and Njoroge (2017), in that people who abuse drugs got enticed and aware from advertisement. Furthermore, $34 \%$ of the respondents said they abuse substances because their work was stressful while some work more than 8 hours per day, meanwhile long working hours may be stressful and predisposed people to substance abuse. This finding also consistent with findings from (Adeoti 2015), which states that stress in the school; "frustration from the lecturers" workrelated stress can lead to substance abuse. In the same vein, table 4.3 shows the influence of personality traits that predisposed people to substance abuse, $86(71.1 \%)$ of the respondents took substances intending to feel good about themselves and to reduce crowd shyness so that substance can enhance their boldness. The table revealed that seven respondents out of ten picked peer pressure and personality traits as factors that influenced them to substance abuse. This finding was related to the research of (Alhyas, Elarabi, El-Kashef, Wanigaratne, Almarzouqi, Alhosani, \& Ghaferi (2015), Adeoti (2015) and Johnson, Akpanekpo, Okonna, 
ISSN: 2689-9418

Volume 4, Issue 2, 2021 (pp. 38-66)

www.abjournals.org

Adeboye, \& Udoh, (2015), which state that boredom, low self-esteem, and shyness can lead to substance abuse.

Research question 3: What are the common substances of abuse by the respondents?

This study found that out of 121 respondents, 80(66.1\%) and 85(70.2\%) respondents abused alcohol and marijuana respectively as indicated in table 4.4. Moreover, the table also showed that codeine has a prevalence of $33.8 \%$ among respondents. Pentazocine has the lowest consumption rate. It was observed that almost all respondents consumed both alcohol and cannabis in both settings used for this study. These findings were consistent with the research of (United Nations Office of Drug and Crime (UNODC), 2018 and (Gorman \& Anwar, 2015), in that cannabis was the commonest substance of abuse worldwide.

Research question 4: What are the socio-cultural characteristics influencing respondents to substance abuse?

Table 4.1 shows the age distribution of the respondents. $61.15 \%$ were between the ages of 21 $-30,22.3 \%$ were between ages $31-40$ while $8.3 \%$ were between ages $10-20$. This indicates that the majority of the abuser were young adults. This study found that majority of the respondents were male $(90.9 \%)$ while only $9.1 \%$ were female. The finding was in agreement with (Duru, Oluoha., Okafor., Diwe, Iwu., Aguocha, Ohale. \& Nwaigbo, (2017) showed that male students abuse more substance than female. Table 4.4 revealed that $83.3 \%$ o were single in Yaba while $78.2 \%$ were also single in Aro. The majority $79(64.2 \%)$ attained tertiary education compared with $36(29.8 \%)$ that attained secondary school. This finding was inconsistent with Duru, Oluoha., Okafor., Diwe, Iwu., Aguocha, Ohale. \& Nwaigbo, (2017). Also, Kpozehouen et al., and 2015; Pisarska et al., 2016), that people with a low level of education abuse substances than those with higher education.

Hypothesis 1: There is no significant relationship between respondent's psycho-social factors and substance abuse. Table 4.6 shows that the chi-square value obtained for peer pressure is $\left(\mathrm{X}^{2}=8.686, \mathrm{P}=0.34\right)$ and personality trait $\left(\mathrm{X}^{2}=11.222, \mathrm{P}=0.11\right)$ at the significant levels less than 0.05 for the two variables respectively. Since these $\mathrm{p}-$ values were less than 0.05 values, it could be said that peer pressure and personality trait have a relationship with substance abuse among patients in neuropsychiatric hospitals. The finding was consistent with the research conducted by Foo, Tam, and Lee (2015), which states that peer influence played an important role in an individual's drug abuse habits and that people indulge in substance abuse because they are crowd shy and bored. Other studies that agreed with the finding are Alhyas et.al (2015), Johnson, Akpanekpo, Okonna, Adeboye, and Udoh, (2015), Palfrey (2015). However, social media and family settings were not significantly related to substance abuse as shown in table 4.6. Although many studies identified that these factors influence an individual to substance abuse namely (Adeoti (2015), Njoroge (2017), and Rukundo, Kibanja \& Steffens (2017).

Hypothesis 2: There is no significant relationship between respondent's knowledge of substance abuse and abuse of the substance. Table 4.7 shows that the obtained p-value (0.572) is greater than the 0.05 level of significance. Therefore, the null hypothesis was accepted which states that there is no significant relationship between substance abuse and respondent's knowledge. This signifies that knowledge of substance abuse does not influence the consumption of psychoactive substances. The finding was inconsistent with Njoroge (2017) 
ISSN: 2689-9418

Volume 4, Issue 2, 2021 (pp. 38-66)

that respondents' lack of knowledge of the risk of substance use increases their consumption of the psychoactive substance. Also, Haddad, Shotar, and Umlauf (2015), research findings were not consistent with this study finding that in-depth knowledge of the consequences of substance abuse was lacking among people. Therefore, sensitization programs will be more helpful if adequately presented in the early stage of life before people indulge in substance use. Also, intervention packages such as the creation of a more recreational center that can engage people, intensification on core moral values in the society by the religious leaders, teachers, health workers, use of drug abuse screening test scale for every individual in the schools, organizations periodically can be meaningful in reducing substance abuse.

Hypothesis 3: There is no significant relationship between respondent's socio-cultural characteristics and substance abuse. Table 4.8 shows that the chi-square value obtained for marital status is $\left(\mathrm{X}^{2}=31.455, \mathrm{P}=0.002\right)$ and occupation $\left(\mathrm{X}^{2}=25.266, \mathrm{P}=0.046\right)$ at the significant levels less than 0.05 for the two variables respectively. Since these $\mathrm{p}-$ values were less than 0.05 values, it could be said that marital status and occupation have a relationship with substance abuse among patients in neuropsychiatric hospitals. Good harmonious relationship with the spouse and good working conditions, satisfaction with the job, and flexibility of the curriculum in the school can go a long way to reduce substance abuse in our society. The table also revealed the calculated $\mathrm{P}$ - values for gender, religion, and level of education $(0.789,0.699$, and 0.819$)$ are greater than the 0.05 level of significance. Therefore, there is no relationship between gender, level of education, and religion with substance abuse. The findings were inconsistent with Anyanwu, Ibekwe, and Ojinnaka (2016) and Afolabi, Oladotun \& Chinwe (2015), which state that substance abuse is being influenced by unstable family structure, level of education.

\section{SUMMARY, CONCLUSION, AND RECOMMENDATIONS}

\section{Summary}

Substance abuse is the inability to have voluntary control over substance use resulting in poor health and social functions. The health challenges caused by psychoactive substance misuse have been very disturbing. The factors identified by the study are peer pressure, social media, occupation, personality trait, family setting, knowledge of substance abuse, marital status, level of education, gender as well as religion. Based on the analysis of the study, the findings can be summarized thus:

- The majority of the respondents were between ages $21-30(61.2 \%)$ and $31-$ $40(22.3 \%)$. This is evidence that young adults abused substances that other age groups. This may have a significant impact on the nation's economy because they are the workforce and the majority may be the breadwinner of the family.

- A majority (59.9\%) have good knowledge of the consequences of substance abuse while $39.2 \%$ have a fair knowledge of substance abuse. This could be the fact that respondents' addictive nature rendered them powerless to stop abusing drugs. Also, it may be a result of intervention from medical personnel since respondents have already commenced treatment for substance abuse. 
- It was observed that the majority were influenced by substance abuse by two major factors namely, peer pressure $(69.4 \%)$ and personality trait $(71.1 \%)$. This could be the result of low self-esteem, shyness, or a way of maintaining a social relationship. Family setting and social media also influence some respondents to substance abuse.

- Alcohol (66.1\%) and cannabis (70.2\%) were the major/ commonest drugs respondents' abuse as evident by the responses from patients. Seven out of ten respondents took cannabis. This could be a result of peer pressure and personality trait. Pentazocine was observed to have the lowest prevalence of abuse.

- The study revealed a significant relationship between peer pressure, personality traits, and substance abuse.

- Statistically, it was proven that there was no relationship between knowledge of substance abuse and abuse of the substance. It was revealed that the majority who abuse substances on daily basis have good knowledge of substance abuse. Therefore, sensitization on the consequences of substance abuse at an early stage of life may be helpful before addiction occurred.

- Socio-cultural characteristics such as occupation and marital status have a significant relationship with substance abuse with the p-value of 0.046 and 0.02 respectively.

\section{Conclusion}

Findings from this study identified factors such as peer influence, personality traits, occupation, and marital status. These factors have a significant influence on substance abuse. Also, age group $(20-30)$ abuse substance than other age groups, adequate intervention should be focused on this age group to prevent serious consequences on the national economy because this group constitutes the workforce of the nation. Moreover, knowledge of substance abuse has no relationship with the consumption of substances. Therefore, strengthening moral values and ethics in the family can go a long way in reducing substance abuse.

- It can be concluded that apart from availability and accessibility of drugs, curiosity, a mental status that have been identified by various scholars, occupation, marital status peer pressure, personality trait have a significant influence on substance abuse. Identifying specific factors that influence patients to substance abuse during the initial assessment/interaction section with the patient may be helpful to give prompt/appropriate intervention that will be more effective. Also, substance abuse prevention initiatives should be established in every institution such as schools, correctional centers, for early identification and treatment of individuals at high risk of substance abuse. This program will also provide psychological intervention for those with personality disorders and toxicology screening. The flexibility of the school curriculum should be considered to accommodate those who may see schooling as stressful and use psychoactive drugs as a way of reducing stress. 
ISSN: 2689-9418

Volume 4, Issue 2, 2021 (pp. 38-66)

\section{Recommendations}

Based on the findings from this study, the followings recommendations are made:

- Identify specific factors that influence patients to substance abuse during the initial assessment/interaction section with the patient may be helpful to give prompt/appropriate intervention that will be more effective.

- Government and non - governmental organizations should see a need for establishing more relaxation centers such as sports centers, tourist attraction centers that are affordable and accessible irrespective of socio-economic status. This can engage people's leisure time and divert people's attention from drug consumption.

- Peer influence has been identified as a factor that influences substance abuse. Important moral values/ethics should be strengthened in our social institutions such as family, schools, and religious gathering centers. This can help to build new/or strengthening moral behavior in our society.

- The majority of abusers used drugs because of personality problems, routine psychometric tests for students, workers can be helpful. This facilitates early identification of the personality problem thereby promote prompt intervention before an individual initiates a psychoactive drug use habit as a solution to the problem.

- The establishment of a drug unit in every school that will be coordinated by certified professionals such as nurses, psychologists should be given utmost priority. Drug abuse screening tests can be introduced into every tertiary institution to enhance early detection and to identify people with substance abuse.

- Government should develop a policy that will control the production and importation of alcoholic drinks.

- Regulatory bodies should be devoted more attention to the ways these substances are made available to the populace and impose strict laws on the use of substances. These laws must be strictly followed without bias.

- Psycho-education on the consequences of substance abuse at the early stage of life focusing on primary and secondary school students can be helpful to reduce the prevalence of substance abuse in our society. It is presumed that addiction has not occurred at this stage.

\section{Implications for Nursing}

- Nurses can participate in different management modalities for patients with substance abuse disorder such as conducting individual therapy for clients who have high levels of anxiety and inadequate coping mechanisms.

- The patient should be instructed by the nurses about the alternative sources of satisfaction and coping strategies such as listening to music, yoga exercise, rather than indulging in substance abuse. 
- There is no single intervention appropriate for all individuals with substance abuse. The effective intervention should consider the multiple needs of the individual with substance abuse, not only the drug use. Nurses should help patients to overcome many barriers that negatively influence attitudes toward seeking professional help about substance abuse.

- When the condition of the patient becomes better, nurses should promote understanding of the physical symptoms of addiction and how to deal with them. The nurse can explain to the patient the causes of substance abuse. Immediately before discharge, the nurse should encourage continued participation in the outpatient support system and longterm treatment.

\section{Suggestion for further studies}

- The study mainly covered patients in two specialist hospitals in the southwest of Nigeria, further studies can include patients in other institutions and another geopolitical zone in the country.

- Further studies are required to evaluate risk factors for the hazardous use of specific psychoactive substances among individuals with mental illnesses.

\section{Limitation to the study}

- Effect of covid -19 pandemic that reduces patients' accessibility to the hospital. This made many patients relapse and unfit to participate in the study hence, reduce the number of respondents.

\section{REFERENCE}

Adewumi, B.O (2017). Psychosocial Factors Influencing Substance abuse among Undergraduate.www.preprints.org. Doi:20944/preprints2017//.0151.

Afolabi, A.B, Oladotun A.S \& Chinwe I (2015). Socio-Demographic Variables and Personality Profiles of Patients with Substance Use Disorder in a Drug Abuse Treatment Facility in Nigeria, Journal of Natural Sciences Research, 4(15) retrieved from www.iiste.org.

Ajibade, B.L, Uvomata, M., Akinpelu, A.O.,Adeleke, M.A.,Fabiyi B.O., \& Akinlabi, T (2016). Factors Influencing Substance Abuse amongst Selected Commercial Motorcyclists in Ogbomoso Metropolis, Oyo State, Nigeria. International Journal of Health and Psychology, 4 (3)1-27.Retrieved from www.eajournals.org.

Alhylas, L.,OZaibi,N.A.,ELarabi,H.,El-kashef,A.(2015). Adolescents perception of substance use and factors Influencing it's use. JRSM open 6(2) 205427041456716 www.iwww.imedpub.commedpub.com

Akanni, O, Ehigiator, O, \& Adayonfo (2015). Correlates of psychoactive substance use among Nigerian adolescents. Sahel Medical Journal, 18 (4) 25 - 33. Retrieved from www.imedpub.com 
ISSN: 2689-9418

Volume 4, Issue 2, 2021 (pp. 38-66)

Alhyas, L, Elarabi H, El-Kashef, A, Wanigaratne S., Almarzouqi A, Alhosani, A., \& AlGhaferi H (2015). Adolescents' perception of substance use and factors influencing its use. Journal of social society of medicine. 6(3).

Ani G.N.(2014). Prevalence of substance abuse among senior secondary students in mainland Local government Lagos. Global journal of medicine and public health, 3(6). Retrieved from www.gjmedph.org

Anyanwu1, O,Ibekwe, R., \& Ojinnaka, N., (2016). Pattern of substance abuse among adolescentsecondary school students in Abakaliki. Journal of Cogent Medicine 13(4)9 16. retrieved from htts://doi.org./10.1080/2331205x.2016.1272160.

Arlotta, C.J. (2015). The Best Treatment for Drug Addicts is Community. Retrieved from www.steps torecovery.

Bandura, A. (1988). Organizational Application of Social Cognitive Theory. Australian Journal of Management, 13(2), 275-302. Retrieved from www.wikepedia .org.

Champion, K. E, Teesson, M., \& Newton,N. C., (2016). Patterns and correlates of new psychoactive substance use in a sample of Australian high school students. Journal of Psychology,35(5),338-344 retrieved from htts://doi.org/10.1111/2471 -813x

Collins, B.J, Cuddy, K \& Martin,A.P(2016). Assessing the effectiveness and costeffectiveness of drug intervention programs: UK case study. Journal of Addictive Diseases, 36(1), pp. 5-13. Retrieved from https://doi.org/10.1155/2018/1407649

Dapap, D. D., Okpataku, C. I., \& Audu, M. D. (2020). Use of psychoactive substances among patients presenting at the emergency department of a tertiary hospital. Nigerian postgraduate medical journal, doi;10:4103/npmj.npmj_5_20.27(3), 230.

Duru, C.B, Oluoha U.R, Okafor, C.C, Diwe K.C, Iwu, A.C, Aguocha C.M, Ohale I \& Nwaigbo (2017). Socio-Demographic Determinants of Psychoactive Substance Use among Students of Tertiary Institutions in Imo State, Nigeria. Journal of Addiction Research \& Therapy.8 (3), 2155-6105.

Finch s (2018), the role of nurses in substance abuse, prevention, treatment and management. Foo, Y, Tam \& Lee T (2014). Family Factors and Peer Influence in Drug Abuse: A Study in Rehabilitation Centre. International Journal of Collaborative Research on Internal Medicine \& Public Health (IJCRIMPH). 4(3):190 - 201 retrieved from http://www.iomcworld.com/ijcrimph/

Gebreslassie, M., Feleke, A., \& Melese, T. (2013). Psychoactive substances use and associated factors among Axum University students, Axum Town, North Ethiopia. BMC Public Health 13 (4), 693. htts://doi.org/10.1186/1471-2458-13-693

Gorman, L., \& Anwar, R., (2015). Need's fundamental of mental health Nursing (4 ${ }^{\text {th }}$ edition). Philadelphia, U.S.A, Davis company.

Haddad, L., Shotar A. \& Umlauf M (2015). Knowledge of substance abuse among high school students in Jordan. Journal of Transcultural Nursing 21(2) 124. 136. Retrieved from https://doi.org/10.1177.1043659609357632.

Hagger, M.S. (2019). The Reasoned Action Approach and the Theories of Reasoned Action and Planned Behavior. Journal of researchgate 12(3). Retrieved from https//doi.org/10.1093/OBO/9780199828340-0240

Ikoh, M, . Smah, S.O, OkwanyaI, Clement, U.A, \& Aposhi Z. (2018). Factors Affecting Entry Into Drug Abuse Among Youths in Lafia Metropolis: Implications on Security. journals.sagepub.com/home/sgo 8(2) retrieved from https://us.sagepub.com/enus/nam/open-access-at-sage). 
ISSN: 2689-9418

Volume 4, Issue 2, 2021 (pp. 38-66)

Israilova, M. (2017). substance abuse disorder patient case. Journal of health care communications. 3 (1) 11- 17.Rretrieved from www.imedpub.com

Jakovljevic, M. B., Jovanovic, M., \& Lesch, O. M. (2015). Accessibility and affordability of alcohol dependency medical care in serbia. Front. Psychiatry 12(2) 192. htts://doi.org/10.3389/fpsyt.2015.00192

Janicijevic, K, Kocic C.C, Radevic, S.R, Jovanovic M.R, \& Snezana M. ( 2017).

Radovanovic1Socioeconomic Factors Associated with Psychoactive Substance Abuse by Adolescents in Serbia. Frontiers in Pharmacology 8 (3) 366 -378 retreieved from www.frontiersin.org

Johnson, O .E, Akpanekpo, E. I, Okonna, E.M, Adeboye S.E, \& Udoh, A.J. (2017). The Prevalence and Factors affecting Psychoactive Substance Use among Undergraduate Students in University of Uyo, Nigeria. Journal of Community Medicine and Primary Health Care. 29 (2) 11-22

Jones, J.S, Fitzpatrick, J.J. \& Rogers, V.L.(2014). Psychiatric Mental Health Nursing: An Interpersonal Approach. (2nd edition), U.S.A. Springer.

Kneisl, C.R \& Trigoboff, E. (2014); contemporary Psychiatric Mental Health Nursing.

Linda, M,G. \& Anwar, R.F (2015). Needs Fundamental of Mental Health Nursing (4th Edition) Philadelphia, U.S.A. Davis Company.

Lundberg, K, M. (2017). Environmental Risk Factors."The Science of Addiction: Genetics and the Brain. Retrieved from www.Learn.Genetics.utah.edu.

McAlister, A, L. Perry C,L, \& Parcel G,S. (2008). How Individuals, Environments, and Health Behaviors Interact: Social Cognitive Theory. Health Behavior and Health Education: Theory, Research, and Practice (4th Edition) San Francisco, CA: John Wiley \& Sons,Inc; 2008: 169-188.

National Institute of Drug abuse, ( 2015). Consequences of Drug abuse in South Africa. New York: United Nations.

National Institute of Drug Abuse (NIDA). (2010). The Neurobiology of Drug Addiction. Section II:The Reward Pathway and Addiction.Retrieved from http://www.nida. nih.gov/pubs/teaching/teaching2/Teaching3.html

Njoroge M.W (2017), Knowledge, Attitude and Practices on Substance Use Disorders by University Students. Journal of Alcoholism \& DrugDependence ,5(6) DOI: 10.4172/2329-

Ozta, G. D, Kalyon,A, ErtuLrul,A, GündoLdu, C, BalcJoLlu, SaLlan, Y, Bilge U \& Karahan, S (2018). Evaluation of Risk Factors Affecting Substance Use among TenthGrade Students. journal of biomedical research international 14(5) $11-20$ https://doi.org

Palmo, A.J, Weikel, W,J. \& Borsos, D.P (2011); Foundation of Mental Health Counselling 4th Edition U.S.A. Charles C. Thomas.

Personality Profiles of Patients with Substance Use Disorder in a Drug Abuse Treatment Facility in Nigeria, 4 (15) $1-6$. Retrieved from www.iiste.org.

Questionnaire survey. BMC Public Health journal Retrieved fromhttps://www.drugabuse.gov/international/abstracts/social-consequences-drugabuse-in-south-asia

Salazar, M. J, Castellanos, C. E, Enríquez, H . C, González, A. P, Carral, H. B, Cabrera, M.M, López, P.R \&García, E. A (2018). Alcohol Consumption and Academic Performance in High School Students. International.Journal of Drug Development and Research, 10(2): 1-6 retrieved from www.imedpub.com 
ISSN: 2689-9418

Volume 4, Issue 2, 2021 (pp. 38-66)

Santrock, J.W. (2014). A Topical Approach to Lifespan Development 4th edition. New York, NY: McGraw-Hill Companies, Inc. pp. 26, 30, 478

Townsend, M.C (20124 ); Essential of Psychiatric \& Mental Health Nursing. 6th edition, U.S.A. David publisher.

United Nation Office On Drug \& Crime. World drug report, (2018) retrieved from https://www.unodc.org/wdr2018

United Nations office of Drug and Crime, (2018). Drugs use in Nigeria, Retrieved from https://www.unodc.org/documents/dataananalysis/statistics/Drugs/Drug_Use_Survey_N igeria

United Nations Office on Drugs and Crime (UNODC), (2015). World drug report.

Vinish, V \& Vimala, P,. (2018). Knowledge on Effects of Substance Abuse among Adolescents: - A Descriptive Study. Indian Journal of Public health research and Development retrieved from www.eajournals.org.

World Drug Report, (2018). United Nations publication retrieved from https://www.unodc.org www.imedpub.com/Journal of Addictive Behaviors and Therapy

Zarrouq, B,. Bendaou, B, .El Asri1, A, Achour, L, Rammouz I, Aalouane R,Lyoussi, B, Khelafa, S, Bout, A, Berhili, N. Hlal H, Najdi H, Nejjari, C,. \& El Rhazi, K.(2016). Psychoactive substances use and associated factors among middle and high school students in the North Center of Morocco: a cross-sectional

Zimić, J. I. (2018). Family and Psychosocial Developmental Features of Drug Dependent Womenand a Specific Needs for Treatment and Social Reintegration. Journal of addictive behavior and therapy. 13 (2). Retrieved from www.imedpub.com 